\title{
Two Jurassic salamanders with stomach contents from Inner Mongolia, China
}

\author{
DONG LiPing ${ }^{1,2^{*}}$, HUANG DiYing ${ }^{3 *} \&$ WANG Yuan ${ }^{1}$ \\ ${ }^{1}$ Key Laboratory of Evolutionary Systematics of Vertebrates, Institute of Vertebrate Paleontology and Paleoanthropology, Chinese Academy of \\ Sciences, Beijing 100044, China; \\ ${ }^{2}$ Graduate University of Chinese Academy of Sciences, Beijing 100049, China; \\ ${ }^{3}$ State Key Laboratory of Palaeobiology and Stratigraphy, Nanjing Institute of Geology and Palaeontology, Chinese Academy of Sciences, \\ Nanjing 210008, China
}

Received June 1, 2011; accepted July 26, 2011; published online September 27, 2011

Conchostracans and corixids are part of the diet of extant salamanders, an ecologically important fact in a lacustrine environment. Here we report their discovery in the guts of the aquatic Jurassic salamanders Jeholotriton paradoxus and Chunerpeton tianyiensis, formerly abundant at Daohugou, Ningcheng County, Inner Mongolia, China. This reveals something of the ecology of this important, ancient, vertebrate and invertebrate assemblage. The new fossil evidence indicates the highly selective feeding of these Jurassic salamanders; Jeholotriton preyed only on juveniles of the conchostracan Euestheria luanpingensis, and Chunerpeton only on the corixid Yanliaocorixa chinensis. We can infer the dietary differences as a consequence of different jaw and hyoid structures; and thus niche partitioning in Jurassic salamanders.

Jurassic caudate, Jeholotriton, Chunerpeton, stomach contents, Daohugou, Inner Mongolia

Citation: $\quad$ Dong L P, Huang D Y, Wang Y. Two Jurassic salamanders with stomach contents from Inner Mongolia, China. Chin Sci Bull, 2012, 57: 72-76, doi: $10.1007 / \mathrm{s} 11434-011-4729-\mathrm{z}$

The Jurassic site at Daohugou, Ningcheng County, Inner Mongolia, China, has yielded an important assemblage of fossil plants [1], invertebrates (e.g. anostracans, conchostracans, spiders, harvestmen, and insects) [2,3], and vertebrates (e.g. salamanders, lizards, feathered dinosaurs, pterosaurs, and mammals) [4-6]. The caudates from this locality are represented by hundreds of specimens, and include two dominant neotenic species, Jeholotriton paradoxus Wang, 2000 [7] and Chunerpeton tianyiensis Gao et Shubin, 2003 [8], as well as the metamorphosed Liaoxitriton daohugouensis Wang, 2004 [9]. Many are well-preserved as articulated skeletons, even retaining soft tissue impressions. In addition to the caudates living in the water, there were many aquatic invertebrates such as conchostracans, anostracans, bivalves, and aquatic insects, which could have provided a sufficient food supply for the contemporaneous salamanders $[2,10]$.

*Corresponding authors (email: marie.donglp@gmail.com; huangdiying@sina.com)
We here present rare occurrences of fossilized stomach contents in the two neotenic caudates from Daohugou, and discuss their ecology. This is the first report of well-established fossil caudates with food in their stomachs, and these specimens provide important evidence supporting hypotheses about ecological interactions in the Jurassic ecosystem of Daohugou.

Among more than 600 caudate specimens recovered from Daohugou, two specimens of Jeholotriton paradoxus (IVPP V14195, IVPP V18083) and nine specimens of Chunerpeton tianyiensis (IVPP V18084-V18092) have been discovered with conchostracans or insects as stomach contents. All 11 of these specimens are preserved as complete or nearly complete articulated skeletons, some of which (IVPP V14195, IVPP V18087, and IVPP V18091) also have soft tissue impressions (e.g. eyes, gills, skin, tail fins). These specimens are deposited in the collection of the IVPP (Institute of Vertebrate Paleontology and Paleoanthropology, 
Chinese Academy of Sciences).

Two specimens with stomach contents (IVPP V14195 and IVPP V18083) can be referred to Jeholotriton paradoxus on the basis of the following key diagnostic characters [11]: the vomerine tooth row with a large anterior patch and a dentigerous bar extending posteriorly; three pairs of external gills with no ossified rakers; and the coracoid end of the scapulocoracoid slightly expanded and rounded.

IVPP V14195 is a well-preserved, articulated skeleton split into part and counterpart on tuffaceous shale slabs. The body is mainly in lateral view, showing a clear impression of the outline, external gills and a tail fin. At $96 \mathrm{~mm}$ in length (from the snout to the tip of the tail), it is considerably shorter than the $135 \mathrm{~mm}$ adult holotype, suggesting this animal was a juvenile. There are more than 50 conchostracan carapaces in the abdominal region of the animal; this area is delineated by a soft tissue impression (Figure 1(a)). The carapace valves are identified as stomach contents based on the following lines of evidence: (1) The valves are clustered, overlapping heavily, and the margin of the conchostracan cluster below the vertebral column and between the forelimbs and hind limbs is within the outline of the abdominal region. (2) The carapaces are relatively small ( $\leqslant 3 \mathrm{~mm}$ in length), whereas the conchostracans from Daohugou bed are normally dispersed and have a large size range (1-7 $\mathrm{mm}$ in length and mostly $>5 \mathrm{~mm}$ in IVPP V14195). This suggests selection of prey size by the predator. (3) The conchostracans in the abdominal area appear relatively circular, in contrast to the more or less oval carapace valves outside the salamander's body. Their rounded shape could be a result of softening of the chitinous valves during digestion. (4) A proportionally large number of the conchostracans in the abdominal region are preserved dorsally with the two valves open, suggesting the adductor muscle had been digested before burial (Figure 1(c)). No tooth marks are present on the surfaces of the conchostracan valves in the abdomen, implying that they must have been swallowed whole rather than bitten. The conchostracans in the abdominal region appear to occupy nearly the entire body cavity, probably because the carapaces broke the gut and entered the coelom as they were pressed during burial. All the conchostracans on the slabs can be identified as belonging to a single species Euestheria luanpingensis [12].

The situation in IVPP V18083 is quite similar. More than 100 conchostracans are clearly present in the abdominal region between forelimb and hind limb, although this animal is smaller than IVPP V14195 and is poorly preserved with the skull disarticulated and the postcranial skeleton partly missing (Figure 1(b)). The rounded, eaten carapace valves seen in this specimen are similarly small in size (ca. $2 \mathrm{~mm}$ in length), and are more clustered and more overlapping than those in IVPP V14195. It is obvious that more organic residue (shown by the darker color) is preserved on the surfaces of the carapaces in the gut of the salamander than on those outside, providing further evidence for their being the food of the predator.

It is not surprising to discover that a Jurassic salamander ate conchostracans. Werneburg [13] described a specimen of the temnospondyl Apateon with a skull length of $10 \mathrm{~mm}$, whose stomach contents included small conchostracans. Apateon is probably close to the ancestral salamander condition [14]. Extant caudates (e.g. Ambystoma cingulatum [15]; Salamandra salamandra [16]) have also been reported as preying on conchostracans. Gao and Shubin [8]

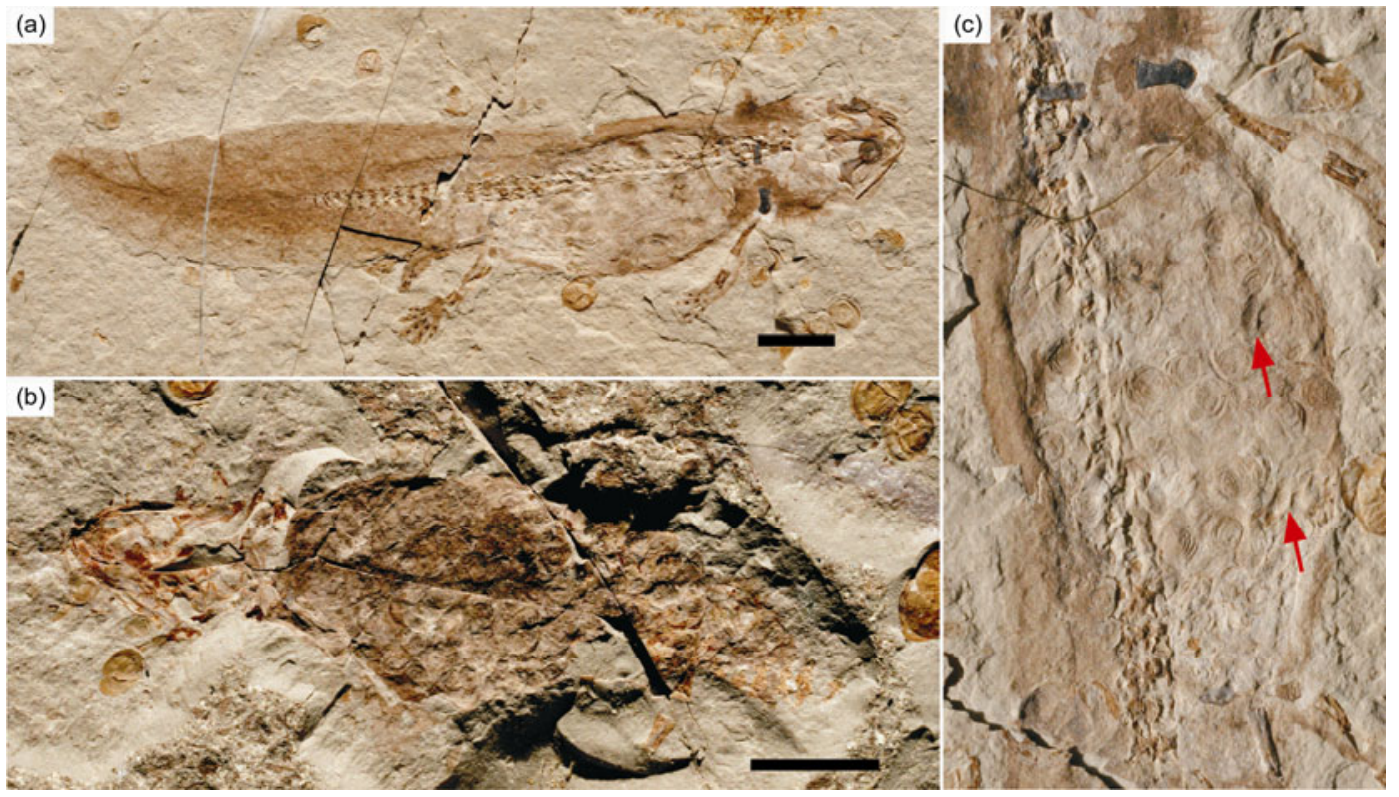

Figure 1 Jeholotriton paradoxus with conchostracans preserved as stomach contents. (a) IVPP V14195B; (b) IVPP V18083; (c) enlargement of conchostracans in the abdomen of IVPP V14195B. Red arrows indicate those dorsally preserved with two valves open. Scale bars: $10 \mathrm{~mm}$. 
mentioned a caudate specimen which was not referred to any established taxa, that contained conchostracans in its gut cavity. This specimen can be identified as Jeholotriton paradoxus based on osteological characters (page 427, Figure $3[8]$ ). The specimens of Jeholotriton paradoxus with stomach contents provide evidence of conchostracans preyed on by a Chinese Mesozoic caudate of known taxonomic affinity.

Chunerpeton tianyiensis is another caudate that commonly occurs in the vicinity of Daohugou. It is characterized by a set of osteological features that clearly distinguishes it from Jeholotriton paradoxus, including the vomerine tooth row that runs parallel to the maxillary arcade, an anterior ramus of the pterygoid that extends anterolaterally and then curves medially toward the lateral end of the vomer, and the coracoid end of the scapulocoracoid that is roughly rhomboid $[4,8,11]$. One especially distinctive character of Chunerpeton tianyiensis is the presence of ossified gill rakers in its external gills, even at very early developmental stages. In contrast, Jeholotriton paradoxus may preserve beautiful impressions of three pairs of external gills, but always lacks ossified gill rakers. Nine specimens with stomach contents can be referred to Chunerpeton tianyiensis, ranging from 30 to $62 \mathrm{~mm}$ in length (from the snout to the tip of the tail). The largest known skeleton is $500 \mathrm{~mm}$ long (personal observation by Wang Yuan). Thus the specimens considered here all appear to represent juveniles. This conclusion is further supported by the fact that their skulls were only lightly ossified.

The stomachs of these nine Chunerpeton tianyiensis all contain an insect that we have identified as Yanliaocorixa chinensis, a common member of the Yanliao entomofauna $[2,17,18]$. Some authors referred Yanliaocorixa chinensis to a new taxon, Daohugocorixa vulcanica [19]. Yanliaocorixa chinensis, the dominant corixid in the Daohugou fauna, is abundant and is usually preserved as a complete individual at different instars. The corixids found in the stomachs of these salamanders are 5-6 $\mathrm{mm}$ in length, and exclusively represent adults or last larval instars (Figure 2), suggesting size-based selective feeding of the live predator. The head or fore wings of these corixids are sometimes disarticulated, indicating that the joints was digested in the stomach (Figure 2(b),(c)). In addition, there are no tooth marks on the eaten corixids, indicating that they were probably swallowed whole. Chunerpeton could eat more than one individual corixid in a meal, as shown in Figure 2(b), and sometimes took many more as indicated by IVPP V18089, in which as many as five corixids can be observed in the abdominal region.

Some ecological studies of Daohugou insects have assumed that caudates were the dominant and large aquatic animal and would have fed on insects [20]. The stomach contents of the nine specimens of Chunerpeton tianyiensis discussed in this paper help to establish a direct predator-prey relationship. That Chunerpeton tianyiensis preyed on Yanliaocorixa chinensis, sheds light on interactions between vertebrates and invertebrates in a Jurassic fauna.

It is clear that the aquatic salamanders at Daohugou resembled their modern counterparts in having prey selection, not only size-based but also type-based. Of the abundant aquatic invertebrates in the Daohugou fauna, the conchostracans were benthic except during reproductive periods and early developmental stages, the mayfly nymphs were benthic or endobenthic, the corixids mostly swam near the substrate. The two forms of neotenic salamander took different types of invertebrates as food: Jeholotriton preyed only on conchostracans, and Chunerpeton only on corixids. At present, no evidence indicates that they fed on other invertebrates.

Living newts tend to change their diet as they grow [21]. Younger juveniles generally feed on very small prey, such as protozoans and vegetation fragments. As growth proceeds, they begin to forage on moderately sized invertebrates, such as corixids and minute crustaceans, and then switch to even larger prey that may include small juvenile conspecies [22]. As described above, juvenile Jeholotriton preyed on only small conchostracans $\sim 2 \mathrm{~mm}$ long, and juvenile Chunerpeton ate only adult corixids 5-6 mm long. The adults of each salamander taxon presumably took larger prey, such as fishes or frogs, as do their living relatives. However, no adult specimens of Jeholotriton or Chunerpeton have been found with stomach contents preserved, so the adult diet of these taxa remains uncertain.

Neotenic Daohugou salamanders preyed on small conchostracans or adult corixids because these suited their foraging habits. In living salamanders, such as Salamandra salamandra, prey must be moving at a certain velocity to stimulate prey-catching behavior [23]; this may also have been the case in the ancient salamanders. Conchostracans often attach to or hide within vegetation or remain quiescent on the substrate, except during reproductive periods or at early developmental stages, when active swimming is more common. Individuals of Euestheria luanpingensis that were about $2 \mathrm{~mm}$ in size probably retained the ability to swim freely, and were thus readily preyed upon by Jeholotriton. Probably for the same reason, Chunerpeton fed only on adult corixids rather than on young corixids or mayfly nymphs.

Jurassic caudates with gut contents can also provide insights into the feeding behaviors and foraging environments of these ancient, tailed amphibians. Whereas lungless terrestrial salamanders capture prey with a rapid flick of the tongue, water-dwelling salamanders usually suck in and swallow aquatic prey (such as conchostracans and corixids) [21]. The neotenic salamanders Chunerpeton and Jeholotriton can be expected to have used the sucking-and-swallowing strategy of their extant aquatic relatives. It is notable that the ingested corixids are relatively large in proportion to the length of the predator (Chunerpeton), while the conchostracans ingested by Jeholotriton are relatively small. This may be the result of different hunting abilities, consequent from differences in jaw and hyoid morphology. Chunerpeton 

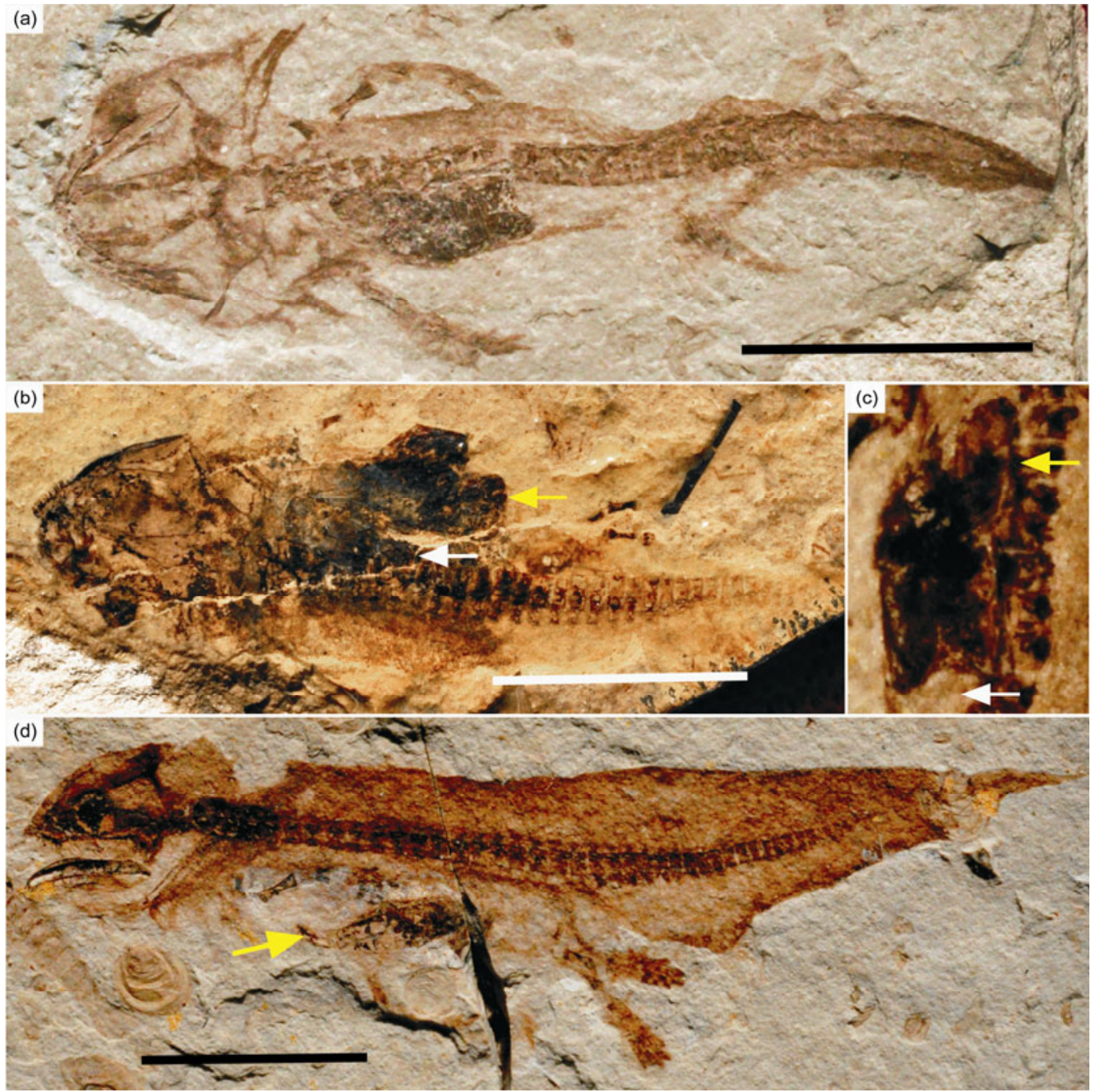

Figure 2 Chunerpeton tianyiensis with corixids preserved as stomach contents. (a) IVPP V18085 with one corixid in its belly; (b) IVPP V18086 with two corixids shown by arrows; the yellow arrow indicates a corixid with a disarticulated wing on its right side; (c) enlarged view of the corixid in the belly of IVPP V18085; the yellow arrow indicates the disarticulated head, and its original position is indicated by the white arrow; (d) IVPP V18087 preserved laterally with one corixid in its belly showing its hind leg. Scale bars: $10 \mathrm{~mm}$.

apparently had a longer and better developed jaw and better ossified hyobranchial elements than Jeholotriton [8,11], and therefore had a bigger mouth gape and buccal expansion during preying which in turn produced a higher suction force, enabling it to take larger prey [24].

Extant corixids mostly inhabit ponds and slow-moving streams where they forage on the bottom ooze [25]; this was probably also true of the corixids at Daohugou. This implies that during the Jurassic there were probably seasonal lakes at Daohugou in which water was nearly or entirely stagnant, and therefore enabled aquatic insects such as corixids to thrive. The Jurassic cryptobrachid Chunerpeton has a flat skull, as does its living relative the Chinese giant salamander, Andrias davidianus, which is benthic [4,8]. In addition to the evidence that corixids formed part of its diet, the general resemblance with Andrias davidianus suggests that Chunerpeton may have foraged near the bottom.
The different diets of Chunerpeton and Jeholotriton indicate that they occupied different ecological niches. The other salamander in the Daohugou fauna, Liaoxitriton, is mainly terrestrial, presumably preying on different food and thus also occupying a different niche. This lack of competition for food may have allowed these three Daohugou Jurassic salamanders to flourish.

Our thanks go to Dr. Corwin Sullivan of the Institute of Vertebrate Paleontology and Paleoanthropology (Beijing, China) and Prof. Susan E. Evans of University College London (London, United Kingdom) for comments on an earlier draft and help with English. We also would like to thank Drs. Shen Yanbin and Li Gang of the Nanjing Institute of Geology and Palaeontology (Nanjing, China) and Dr. Jiang Baiyu of the Nanjing University (Nanjing, China) for the helpful discussion. This work was supported by the National Natural Science Foundation of China (41072015) and the Knowledge Innovation Program of the Chinese Academy of Sciences (KZCX2-YW-QN104). 
1 Zhou Z Y, Zheng S L, Zhang L J. Cretac Res, 2007, 28: 348-362

2 Huang D Y, Nel A, Shen Y B, et al. Prog Nat Sci, 2006, Special Issue: 308-312

3 Huang D Y, Selden P, Dunlop J. Naturwissenschaften, 2009, 96: 955-962

4 Wang Y, Evans S E. Vert PalAsiat, 2006, 44: 60-73

5 Zhou Z H, Wang Y. Sci China Earth Sci, 2010, 53: 1894-1907

6 Ji Q, Luo Z X, Yuan C X, et al. Science, 2006, 311: 1123-1127

7 Wang Y. Vert PalAsiat, 2000, 38: 100-103

8 Gao K Q, Shubin N H. Nature, 2003, 422: 424-428

Wang Y. Chin Sci Bull, 2004, 49: 858-860

10 Shen Y B, Chen P J, Huang D Y. J Stratig, 2003, 27: 311-314

11 Wang Y, Rose C S. J Vert Paleont, 2005, 25: 523-532

12 Zhang W T, Shen Y B, Niu S W. Acta Palaeont Sin, 1987, 26: $111-129,6$ pls

13 Werneburg R. Freiberger Forschungshefte C, 1986, 410: 88-101
14 Carroll R. N Jb Geol Paleont Abh, 2004, 232: 157-180

15 Whiles M R, Jensen J B, Palis J G, et al. J Herpet, 2004, 38: 208-214

16 Blaustein L. Oecologia, 1997, 110: 212-217

17 Hong Y C. Middle Jurassic Fossil Insects in North China (in Chinese). Beijing: Geological Publishing House, 1983

18 Tan J J, Ren D. Acta Zoo Taxonom Sin, 2002, 27: 428-434

19 Zhang J F. Paleont J, 2010, 44: 515-525

20 Zhang J F. Can J Earth Sci, 2006, 43: 9-22

21 Duellman W E, Trueb L. Biology of Amphibians. Baltimore and London: Johns Hopkins University Press, 1986

22 Wells K D. The Ecology and Behavior of Amphibian. Chicago: University of Chicago Press, 2007

23 Luthardt G, Roth G. Zeitschr Tierpsychol, 1979, 51: 252-259

24 Deban S M. Vertebrate Biomechanics and Evolution. Oxford: BIOS Scientific, 2003. 161-178

25 Lauck D R. Bull Calif Ins Surv, 1979, 21: 87-123

Open Access This article is distributed under the terms of the Creative Commons Attribution License which permits any use, distribution, and reproduction in any medium, provided the original author(s) and source are credited. 